\title{
Exercise-induced bronchoconstriction: new evidence in pathogenesis, diagnosis and treatment
}

\author{
Matteo Bonini and Paolo Palange
}

\begin{abstract}
The acute airway narrowing that occurs as a result of exercise is defined exercise-induced bronchoconstriction (EIB). Most recent guidelines recommend distinguishing $E I B$ with underlying clinical asthma $\left(E \mid B_{A}\right)$ from the occurrence of bronchial obstruction in subjects without other symptoms and signs of asthma ( $\left.E I B w_{A}\right)$. ElB has been in fact reported in up to $90 \%$ of asthmatic patients, reflecting the level of disease control, but it may develop even in subjects without clinical asthma, particularly in children, athletes, patients with atopy or rhinitis and following respiratory infections. Both $\mathrm{EIB}_{\mathrm{A}}$ and $\mathrm{EIBW_{ \textrm {A } }}$ have peculiar pathogenic mechanisms, diagnostic criteria and responses to treatment and prevention. The use of biomarkers, proteomic approaches and innovative technological procedures will hopefully contribute to better define peculiar phenotypes and to clarify the role of EIB as risk factor for the development of asthma, as well as an occupational disease.
\end{abstract}

Keywords: Exercise, Bonchoconstriction, Asthma, Athlete, Sport, Doping, Phenotypes, Biomarkers, Beta-2 agonist

\section{Review}

\section{Introduction}

The term exercise-induced bronchoconstriction (EIB) describes the acute airway narrowing that occurs as a result of exercise [1]. It has long been known that physical exercise may trigger symptoms of asthma. However, the interest for an objective study on this phenomenon may be dated back to 50 years ago, when Jones and co-workers focused on the physiologic response to exercise in asthmatic children and named the airway obstruction after an exercise challenge exercise-induced asthma (EIA) [2]. Subsequent research defined the different patterns of response to exercise in asthmatic patients, the effect of type, intensity and duration of challenges, and the influence of antiasthmatic drugs on EIA.

In reviewing these studies, Godfrey concluded that, despite of "some exceptions, there has been no evidence that EIA occurs in patients other than asthmatics, and although sporadic cases have been reported where exercise appears to have been the only precipitant of asthma in a patient (usually an adult), careful investigation has usually revealed other clinical and physiological manifestations of bronchial asthma" [3].

\footnotetext{
* Correspondence: matteo.bonini@uniroma1.it

Department of Public Health and Infectious Diseases, "Sapienza" University of Rome, Viale dell'Universita', 37, 00185 Rome, Italy
}

Although some authors consider EIA as a distinct asthma phenotype [4], it is quite evident that exercise may trigger bronchial obstruction and clinical symptoms in almost all asthmatic patients, independently from the causes and mechanisms of the underlying asthma. In fact, the prevalence of EIA has been reported in up to $90 \%$ of asthmatic patients, reflecting the level of disease control, with EIA occurring more frequently in more severe and uncontrolled asthmatic patients [5].

However, the concept that exercise may induce bronchial obstruction in asthmatic patients only is in question [6]. Exercise-induced bronchoconstriction (EIB) may in fact develop even in subjects without clinical asthma. This is particularly true in children, athletes, and patients with atopy or rhinitis, or following respiratory infections [7-10]. It is not easy, however, to report prevalence rates in these populations because they also depend on the type and intensity of exercise, as well as the environmental conditions in which the challenge is performed. Certainly, EIB that occurs in athletes without clinical asthma has peculiar clinical and pathologic features [11] and often disappears after discontinuation of intense training [12].

To bring some clarity to this still controversial issue, a Practice Parameter, jointly developed by the American Academy/College of Allergy Asthma and Immunology (AAAAI/ACAAI) [13], and more recently an American 
Thoracic Society Clinical Practice Guideline [14], recommended to abandon the term of EIA (because exercise is not the cause, but only a trigger of asthma) and to name EIB with asthma $\left(\mathrm{EIB}_{\mathrm{A}}\right)$, the occurrence of bronchial obstruction after exercise in asthmatic patients, and EIB without asthma $\left(\mathrm{EIBw}_{\mathrm{A}}\right)$, the occurrence of bronchial obstruction in subjects without other symptoms and signs of clinical asthma.

\section{Pathogenesis}

EIB was initially thought to be secondary to a mediator release from mast cells [3]. This hypothesis was also supported by the refractory period observed after a positive exercise challenge, interpreted as the time needed for mast cell recharge, and by the preventive effect offered by mast cell stabilizing agents, such as sodium cromoglycate. Although mediator release does contribute to cause EIB, pathophysiologic changes induced by intense exercising are definitely more complex. At present, it is widely accepted that hyperventilation through the mouth associated with intense exercise causes the need for humidifying and heating large volumes of air during a short period of time. Elegant experiments performed by S.D. Anderson and coworkers [15] show that the respiratory water loss and the increase in osmolarity of the airways surface liquid represent the major determinants of EIB (osmotic theory). In fact, the dryer and cooler is the inspired air and the higher is the ventilation, the greater is the likelihood of a positive response to exercise, which also explains the higher prevalence of EIB in winter sport disciplines [16]. The vasodilation associated with airways rewarming (thermal theory) may also play a role in inducing bronchial obstruction after exercise [17].

In $\mathrm{EIB}_{\mathrm{A}}$, the previously mentioned mechanisms only represent a trigger of the underlying airway hyperreactivity in subjects with different phenotypes of asthma not under control.

However, in $\mathrm{EIBw}_{\mathrm{A}}$, the epithelial damage of a large number of bronchial tree divisions down to peripheral airways represents the predominant pathogenic mechanism [18]. A direct effect of viral infections, occupational agents and exercise may in fact represent a causal mechanism of bronchoconstriction, alternative to the classic eosinophilic mast cell-dependent pathway occurring in allergic asthma [19]. The role of epithelial damage and of substances released by the epithelium and found in sputum, such as interleukin-8 and leukotrienes [20, 21], and in serum or urines, such as Nerve Growth Factor (NGF) and the Clara cell protein CC16 [20, 22], may also explain the heterogeneous inflammatory response reported in $\mathrm{EIBw}_{\mathrm{A}}$ [23]. The increase of columnar epithelial cells in induced sputum [20] is, in fact, associated with a neutrophilic or mixed eosinophilic-neutrophilic inflammation $[24,25]$. The importance of aquaporin, expressed by the subepithelial glandular cells, in regulating the water transport through the epithelium [26], as well as the increased mucus production, as shown by the increased expression of MUC5AC in induced sputum [27], may be also relevant in $\mathrm{EIBw}_{\mathrm{A}}$.

At last, autonomic dysregulation may also have a role in causing bronchial obstruction in $\mathrm{EIBw}_{\mathrm{A}}$ [28], both through the basal increased parasympathetic tone shown in athletes and through reflex mechanisms induced by exercise.

\section{Diagnosis}

Research performed over the past twenty years in athletes has consistently revealed a poor relationship between the presence of 'asthma-like' symptoms and objective evidence of EIB [29, 30]. Furthermore, pulmonary function tests at baseline appear to be poorly predictive of EIB in athletes, often being within the normal ranges even in the presence of disease [31]. Thus, in order to establish a secure diagnosis of EIB it is important to perform objective testing to confirm dynamic changes in airway function [14].

\section{Bronchoprovocative tests (BPTs)}

After a careful history and physical examination, measuring the change in the forced expiratory volume in the $1 \mathrm{~s}\left(\mathrm{FEV}_{1}\right)$ before and after a standardized exercise challenge test (ECT), in the laboratory or in the field, represents the most intuitive and commonly adopted approach to diagnose EIB [32]. An ECT should be performed in subjects with $\mathrm{EIB}_{\mathrm{A}}$ only when their baseline $\mathrm{FEV}_{1}$ is $\geq 70 \%$ of normal.

$\mathrm{A} \geq 10 \%$ fall in $\mathrm{FEV}_{1}$ at any two consecutive timepoint recordings $(1,3,5,10,15,20,25,30 \mathrm{~min}$.) after 6 to $8 \mathrm{~min}$ of treadmill or cycloergometer exercise in ambient conditions $\left(20-25{ }^{\circ} \mathrm{C}\right.$; relative humidity $\left.<50 \%\right)$, is considered diagnostic of EIB [32]. The intensity of exercise should be enough to reach in the first 2-3 min. 40$60 \%$ of the predicted maximum voluntary ventilation (estimated as baseline $\mathrm{FEV}_{1} \mathrm{X} 35$ ) or $80-90 \%$ of the predicted maximal heart rate (calculated by 220 - age). Indeed, it has been reported that the mean fall in $\mathrm{FEV}_{1}$ after an exercise challenge is more than doubled after achieving $95 \%$ of $\mathrm{HR} \max$, compared to $85 \%$ [33]. Standard criteria for laboratory exercise testing may be insufficient to induce a positive response in highly trained individuals and may fail to properly reproduce the bronchoprovocative stimulus experienced by athletes practicing their own sport discipline. Accordingly, sports-specific challenges are also used in athletes. However, these are more difficult to standardize, limiting their application.

Other BPTs may be adopted as surrogate diagnostic tools for EIB. Direct BPTs, (i.e. methacholine and histamine provocation), are accurate to document bronchial hyperreactivity in asthma and in $\mathrm{EIB}_{\mathrm{A}}$, while indirect 
tests, such as eucapnic voluntary hyperpnea, hypertonic saline challenge, and mannitol inhaled powder challenge, better reproduce the effects of exercise on the airways and are therefore more accurate to diagnose $\mathrm{EIBw}_{\mathrm{A}}$ [34]. Though, correlations between exercise tests and other indirect BPTs are at present arguable and vary from test to test [35].

The International Olympic Committee recommends specific thresholds for the various BPTs to document asthma or EIB and to permit the use of anti-asthmatic drugs that are banned or limited by the World AntiDoping Agency (Table 1).

The differential diagnosis of EIB should take into account physiologic limitations; anxiety; exercise-induced laryngeal dysfunctions, hyperventilation and hypoxemia; dyspnoea on exertion in obese or poorly fit individuals; shortness of breath with exercise due to lung diseases (other than asthma), cardiac diseases; anemia; myopathies [14].

In particular, vocal cord dysfunction and structural glottis abnormalities are increasingly recognized as conditions that may mimic EIB [36]. However, in vocal cord dysfunction, inspiratory stridor during exercise usually resolves within $5 \mathrm{~min}$ representing the major differential sign, associated with negative BPT result and poor response to anti-asthmatic drugs. Vocal cord dysfunction may also coexist with EIB.

If pruritus, urticaria or systemic reactions are associated with symptoms of EIB, the diagnosis of exercise-induced urticaria or anaphylaxis should be at last considered [37].

\section{Treatment and Prevention}

Treatment of both $\mathrm{EIB}_{\mathrm{A}}$ and $\mathrm{EIBW}_{\mathrm{A}}$ is essentially based on reversing bronchial obstruction by using short-acting beta-2 agonists [5].

Table 1 International Olympic Committee criteria for the diagnosis of asthma and permission to use of beta-2 agonists: a positive clinical history associated to at least one positive test is required

\begin{tabular}{ll}
\hline Diagnostic procedure & Criteria \\
\hline Pulmonary function & $\mathrm{FEV}_{1}<70 \%, \mathrm{FEV}_{1} / \mathrm{NC}<55 \%$ \\
Bronchodilator test & $\uparrow \mathrm{FEV}_{1} \geq 12 \%$ or $>200 \mathrm{ml}$ \\
Eucapnic Voluntary Hyperpnea (EVH) & $\downarrow \mathrm{FEV}_{1} \geq 10 \%$ \\
Exercise challenge & $\downarrow \mathrm{FEV}_{1} \geq 10 \%$ \\
Methacholine challenge & $\downarrow \mathrm{FEV}_{1} \geq 20 \%$ with a: \\
& $\mathrm{PC}_{20} \leq 4 \mathrm{mg} / \mathrm{ml}$ (for subjects not \\
& taking ICS) \\
& or \\
& $\mathrm{PC}_{20} \leq 16 \mathrm{mg} / \mathrm{ml}$ (for subjects \\
& taking ICS for at \\
& least $1 \mathrm{month}$ ) \\
Hyperosmolar test (Mannitol, Saline) & $\downarrow \mathrm{FEV}, \geq 15 \%$ \\
\hline
\end{tabular}

\section{Pharmacologic Prevention}

Several pharmacologic approaches can be adopted to prevent EIB [38]. Because $\mathrm{EIB}_{\mathrm{A}}$ is a sign of poor asthma control, prevention essentially consists of following international guidelines to achieve asthma control [5]. The potential occurrence of $\mathrm{EIB}_{\mathrm{A}}$ should not prevent asthmatic patients from an adequate practice of physical exercise, which is not associated to an increased risk of asthma developing or worsening and should instead represent part of their treatment [39]. Multiple therapeutic options may be also appropriate to prevent $\mathrm{EIBw}_{\mathrm{A}}$, although usually they do not completely avoid the occurrence of bronchoconstriction, but rather attenuate it or shift the dose-response relationship, so that some submaximal efforts become tolerated. Special precautions must be however taken with respect to the World Anti-Doping Agency (WADA) rules on the use of medications for $\mathrm{EIB}_{\mathrm{A}}$ and $\mathrm{EIBw}_{\mathrm{A}}$ in competitive athletes (Table 2).

Mast cell stabilizers (not available in all countries), disodium cromoglycate and nedocromil sodium, attenuate both $\mathrm{EIB}_{\mathrm{A}}$ and $\mathrm{EIBw}_{\mathrm{A}}$ when inhaled shortly before exercise, but only have a short duration of action [40].

Leukotriene antagonists (i.e. montelukast) have been reported to be effective in preventing $\mathrm{EIB}_{\mathrm{A}}$ [41]. However, protection may not be complete and occurs in approximately $50 \%$ of subjects [42].

Regular use of inhaled corticosteroid (ICS) represents the therapy of choice for asthma control and therefore is a recommended treatment to prevent $\mathrm{EIB}_{\mathrm{A}}$ [43]. The prophylactic administration of ICS has been also suggested in $\mathrm{EIBw}_{\mathrm{A}}$, particularly if physical activity is performed regularly ( $>3$ times per week), representing a repetitive stimulus for the onset of bronchoconstriction [13]. However, the use of ICS in the prevention of EIBw may be controversial. In fact this pharmacological strategy is at present not supported by ad-hoc designed clinical trials and response to treatment may be impaired in subjects with an underlying neutrophilic inflammatory pattern.

Beta-2 adrenergic drugs, both short- and long-acting (SABA and LABA), when given in a single inhaled dose or with intermittent administration before exercise, are the most effective drugs to prevent both $\mathrm{EIB}_{\mathrm{A}}$ and $\mathrm{EIBw}_{\mathrm{A}}$ [44], providing complete protection against exercise (FEV1 fall $<10 \%$ ) in $68 \%$ of subjects [45]. The effect usually lasts 2 to $4 \mathrm{~h}$ for SABA and up to $12 \mathrm{~h}$ for LABA. Heterogeneity observed in the efficacy of beta- 2 adrenergic agents to prevent EIB is not dependent on the type of molecule used, but rather on the population sample studied, with more variable effects reported in children [46].

However, the chronic use of SABA and LABA often results in a reduction of the duration and/or magnitude of protection against EIB with cross-reacting tolerance to other beta- 2 agonists [45, 47]. This loss of efficacy seems to be only partially prevented by ICS [48]. Furthermore, 
Table 2 Most frequently used medications for EIBA and EIBWA and the 2015 World Anti-Doping Agency (WADA) regulations

\begin{tabular}{|c|c|c|}
\hline Treatment & WADA rules & Notes \\
\hline Antihistamines & Permitted & $\begin{array}{l}\text { Second generation molecules should be preferred to avoid } \\
\text { side effects }\end{array}$ \\
\hline Leukotriene modifiers & Permitted & \\
\hline Inhaled steroids & Permitted & \\
\hline Systemic steroids & Prohibited in competition & \\
\hline \multirow[t]{3}{*}{ Beta-2 agonists } & $\begin{array}{l}\text { Inhaled Salbutamol (max } 1600 \mathrm{mcg} / 24 \mathrm{H}) \text {, Formoterol } \\
\text { (max } 54 \mathrm{mcg} / 24 \mathrm{H} \text { ) and Salmeterol permitted }\end{array}$ & $\begin{array}{l}\text { The presence in urine of salbutamol }>1000 \mathrm{ng} / \mathrm{mL} \text { or } \\
\text { formoterol }>40 \mathrm{ng} / \mathrm{mL} \text { is presumed not to be an } \\
\text { intended therapeutic use of the substance and will be } \\
\text { considered as an Adverse Analytical Finding }\end{array}$ \\
\hline & All others prohibited in and out & \\
\hline & competition & \\
\hline Mast-cell stabilizers & Permitted & \\
\hline Anticholinergic agents & Permitted & \\
\hline Immunotherapy & Permitted & SCIT should not be performed before or after physical exerci \\
\hline
\end{tabular}

daily use of SABA and LABA may also result in a worsening of EIB [49]. Therefore, SABA and LABA should be used with caution on a daily basis to prevent EIB. At last, LABA administration should be avoided without concomitant use of ICS according to the U.S. Food and Drug Administration (FDA) warning [50].

Ipratropium bromide prevents $\mathrm{EIB}_{\mathrm{A}}$, although this effect is not consistent among patients and may be variable in the same patient [51]. Whether subjects with $\mathrm{EIBw}_{\mathrm{A}}$ or with a prevalent autonomic imbalance represent an EIB phenotype more responsive to anticholinergic agents represents an interesting hypothesis, still waiting for further experimental testing [52].

Calcium channel blockers, beta-adrenergic receptor antagonists, inhaled furosemide, heparin, and hyaluronic acid have been studied to prevent EIB with inconsistent results [13].

\section{Non-Pharmacologic Prevention}

Similar non-pharmacologic preventive measures can be adopted in both $\mathrm{EIB}_{\mathrm{A}}$ and $\mathrm{EIBw}_{\mathrm{A}}$ [13]. These include, whenever possible, avoiding exercise in an at-risk air environment because of temperature, humidity, and pollutants or specific allergens in sensitized subjects. Gradual warming-up and cooling-down periods are always suggested. Some athletes also take advantage of the refractory period after bronchial obstruction deliberately induced by hyperventilation or by an intense exercise challenge. The use of face masks which warm and humidify the air has been reported to provide benefits. There is at last some evidence that weight loss and dietary factors, such as a low sodium intake, omega- 3 polyunsaturated fatty acids, or a supplementation of ascorbic acid may be helpful in reducing the occurrence and severity of EIB [53].

\section{Conclusions and Perspectives}

Hyperventilation associated with exercise may induce bronchial obstruction in asthmatic patients. However, using the term EIA to define a specific asthma phenotype does not seem appropriate because exercise is only a trigger of a symptom common to all etiologic forms of asthma not under control. EIB may also occur in subjects without clinical asthma. Both $\mathrm{EIB}_{\mathrm{A}}$ and $\mathrm{EIBw}_{\mathrm{A}}$ have peculiar pathogenic mechanisms, diagnostic criteria and responses to treatment and prevention. Further research investigations are desirable to better understand relationships and differences between $\mathrm{EIB}_{\mathrm{A}}$ and $\mathrm{EIBw}_{\mathrm{A}}$ and to definitely affirm if they represent two different phenotypes. With this regards it is suggested to adopt a scientific approach which includes the use of biomarkers, proteomics and innovative technological procedures [54-57]. Moreover, it should be interesting to assess whether children with $\mathrm{EIBw}_{\mathrm{A}}$ are at higher risk for developing clinical asthma with age. At last, it should be questioned if EIB in athletes should be considered an occupational disease due to repeated exercising in inadequate environmental conditions [58].

\section{Competing interests}

The authors declare that they have no competing interests.

\section{Authors' Contributions}

$M B$ run the search strategy and drafted the review. PP reviewed the text and contributed to its final version.

\section{Acknowledgements}

None

Received: 12 December 2014 Accepted: 7 May 2015

Published online: 02 July 2015

\section{References}

1. Anderson SD. Exercise-induced asthma. In: Kay AB, editor. Allergy and Allergic Disease. Oxford: Blackwell Scientific Publications; 1997. p. 692-711. 
2. Jones KS, Buston MH, Wharton MJ. The effect of exercise on ventilator function in the child with asthma. Br J Dis Chest. 1962;56:78-86.

3. Godfrey S. Exercise-induced asthma. In: Clark TJH, Godfrey S, editors. Asthma. London: Chapman and Hall; 1977. p. 57-8.

4. Wenzel SE. Asthma: defining the persistent asthma phenotypes. Lancet. 2006:368:804-13.

5. 2014 Global Initiative for Asthma. Global Strategy for Asthma and Management and Prevention. National Institutes of Health, Lung and Blood Institute, World Health Organization workshop report. Bethesda, Md; Medical Communication Resources; Available from: http://www.ginasthma.org.

6. Bonini S. ElB or not EIB? That is the question. Med Sci Sports Exerc. 2008;40(9):1565-6.

7. Randolph C. Exercise-induced bronchospasm in children. Clin Rev Allergy Immunol. 2008:34(2):205-16.

8. Carlsen KH, Anderson SD, Bjermer L, Bonini S, Brusasco V, Canonica W, et al. Exercise-induced asthma, respiratory and allergic disorders in elite athletes: epidemiology, mechanisms and diagnosis: part I of the report from the Joint Task Force of the European

Respiratory Society (ERS) and the European Academy of Allergy and Clinical Immunology (EAACI) in cooperation with GA2LEN. Allergy. 2008;63(4):387-403.

9. Bonini M, Bachert C, Baena-Cagnani CE, Bedbrook A, Brozek JL, Canonica GW, et al. What we should learn from the London Olympics. ARIA Initiative, in collaboration with the WHO Collaborating Center for Asthma, Rhinitis. Curr Opin Allergy Clin Immunol. 2013;13(1):1-3.

10. Sandrock CE1, Norris A. Infection in Severe Asthma Exacerbations and Critical Asthma Syndrome. Clin Rev Allergy Immunol. 2014 Jul 2. [Epub ahead of print]

11. Parsons JP, Mastronarde JG. Exercise-induced bronchoconstriction in athletes. Chest. 2005;128(6):3966-74.

12. Helenius I, Rytilä P, Sarna S, Lumme A, Helenius M, Remes V, et al. Effect of continuing or finishing high-level sports on airway inflammation, bronchial hyperresponsiveness, and asthma: a 5-year prospective follow-up study of 42 highly trained swimmers. J Allergy Clin Immunol. 2002;109:962-8.

13. Weiler JM, Anderson SD, Randolph C, Bonini S, Craig TJ, Pearlman DS, et al. Pathogenesis, prevalence, diagnosis, and management of exercise-induced bronchoconstriction: a practice parameter. Ann Allergy Asthma Immunol. 2010;105:S1-S47.

14. Parsons JP, Hallstrand TS, Mastronarde JG, Kaminsky DA, Rundell KW, Hull $\mathrm{JH}$, et al. An official American Thoracic Society clinical practice guideline: exercise-induced bronchoconstriction. Am J Respir Crit Care Med. 2013;187(9):1016-27.

15. Anderson SD, Daviskas E. The mechanism of exercise-induced asthma is .... J Allergy Clin Immunol. 2000;106:453-9.

16. Rundell KW, Spiering BA, Evans TM, Baumann JM. Baseline lung function, exercise-induced bronchoconstriction, and asthma-like symptoms in elite women ice hockey players. Med Sci Sports Exerc. 2004;36:405-10.

17. McFadden ER. Hypothesis: exercise-induced asthma as a vascular phenomenon. Lancet. 1990;1:880-3

18. Anderson SD, Kippelen P. Airway injury as a mechanism for exerciseinduced bronchoconstriction in elite athletes. J Allergy Clin Immunol. 2008; $122: 225-35$

19. Holgate ST. Epithelial dysfunction in asthma. J Allergy Clin Immunol. 2007:120:1233-44.

20. Chimenti L, Morici G, Paternò A, Santagata R, Bonanno A, Profita M, et al. Bronchial epithelial damage after a half-marathon in nonasthmatic amateur runners. Am J Physiol Lung Cell Mol Physiol. 2010;298:L857-862.

21. Hallstrand TS. New insights into pathogenesis of exercise-induced bronchoconstriction. Curr Opin Allergy Clin Immunol. 2012;12:42-8.

22. Romberg K, Bjermer L, Tufvesson E. Exercise but not mannitol increases urinary Clara cell protein (CC16) in elite swimmers. Respir Med. 2011;105:31-6.

23. Bonini M, Fioretti D, Sargentini V, Del Giacco S, Rinaldi M, Tranquilli C, et al, Increased nerve growth factor serum levels in top athletes. Clin J Sport Med. 2013;23(3):228-31.

24. Karjalainen E-M, Laitinen A, Sue-Chu M, Altraja A, Bjermer L, Laitinen LA. Evidence of airway inflammation and remodeling in ski athletes with and without bronchial hyperresponsiveness to methacholine. Am J Respir Crit Care Med. 2000;161:2086-91.

25. Bougault V, Loubaki L, Joubert P, Turmel J, Couture C, Laviolette M, et al. Airway remodeling and inflammation in competitive swimmers training in indoor chlorinated swimming pools. J Allergy Clin Immunol. 2012;129:351-8.
26. Moreira A, Delgado L, Carlsen K-H. Exercise-induced asthma: why is it so frequent in Olympic athletes? Expert Rev Respir Med. 2011:5:1-3.

27. Hallstrand TS, Debley JS, Farin FM, Henderson Jr WR. Role of MUC5AC in the pathogenesis of exercise-induced bronchoconstriction. J Allergy Clin Immunol. 2007;119:1092-8.

28. Filipe JA, Falcao-Reis S, Castro-Correia J, Barros H. Assessment of autonomic function in high level athletes by pupillometry. Auton Neurosci. 2003;104:66-72.

29. Ansley L, Kippelen P, Dickinson J, Hull JH. Misdiagnosis of exercise-induced bronchoconstriction in professional soccer players. Allergy. 2012:67(3):390-5.

30. Dickinson JW, Whyte GP, McConnell AK, Harries MG. Impact of changes in the IOC-MC asthma criteria: a British perspective. Thorax. 2005;60(8):629-32.

31. Bonini M, Lapucci G, Petrelli G, Todaro A, Pamich T, Rasi G, et al. Predictive value of allergy and pulmonary function tests for the diagnosis of asthma in elite athletes. Allergy. 2007;62(10):1166-70.

32. Crapo RO, Casaburi R, Coates AL, Enright PL, Hankinson JL, Irvin CG, et al. ATS Guidelines for methacholine and exercise challenge testing 1999. Am J Respir Crit Care Med. 2000;161:309-29.

33. Carlsen $\mathrm{KH}$, Engh G, Mørk M. Exercise-induced bronchoconstriction depends on exercise load. Respir Med. 2000;94(8):750-5.

34. Rundell KW, Slee JB. Exercise and other indirect challenges to demonstrate asthma or exercise-induced bronchoconstriction in athletes. J Allergy Clin Immunol. 2008:122:238-46.

35. Stickland MK, Rowe BH, Spooner CH, Vandermeer B, Dryden DM. Accuracy of eucapnic hyperpnea or mannitol to diagnose exercise-induced bronchoconstriction: a systematic review. Ann Allergy Asthma Immunol. 2011;107(3):229-34.e8.

36. Nielsen EW, Hull JH, Backer V. High prevalence of exercise-induced laryngeal obstruction in athletes. Med Sci Sports Exerc. 2013;45(11):2030-5.

37. Bonini M, Palange P. Anaphylaxis and sport. Curr Opin Allergy Clin Immunol. 2014;14(4):323-7.

38. Carlsen KH, Anderson SD, Bjermer L, Bonini S, Brusasco V, Canonica W, et al. Treatment of exercise-induced asthma, respiratory and allergic disorders in sports and the relationship to doping. Part II of the report from the Joint Task Force of European Respiratory Society (ERS) and European Academy of Allergy and Clinical Immunology (EAACI) in cooperation with GA (2) LEN. Allergy. 2008;63:492-505.

39. Ventura MT, Cannone A, Sinesi D, Buquicchio R, Carbonara M, Di Leo E, et al. Sensitization, asthma and allergic disease in young soccer players. Allergy. 2009;64(4):556-9.

40. Spooner $\mathrm{CH}$, Spooner GR, Rowe BH. Mast-cell stabilizing agents to prevent exercise-induced bronchoconstriction. Cochrane Database Syst Rev. 2003;4 CD002307.

41. Leff JA, Busse WW, Pearlman D, Bronsky EA, Kemp J, Hendeles L, et al. Montelukast, a leukotriene-receptor antagonist, for the treatment of mild asthma and exercise-induced bronchoconstriction. N Engl J Med. 1998;339:147-52.

42. Pearlman DS, van Adelsberg J, Philip G, Tilles SA, Busse W, Hendeles L, et al. Onset and duration of protection against exercise-induced bronchoconstriction by a single oral dose of montelukast. Ann Allergy Asthma Immunol. 2006:97:98-104

43. Koh MS, Tee A, Lasserson TJ, Irving LB. Inhaled corticosteroids compared to placebo for prevention of exercise induced bronchoconstriction. Cochrane Database Syst Rev. 2007;3, CD002739.

44. Anderson SD, Caillaud C, Brannan JD. Beta2-agonists and exercise-induced asthma. Clin Rev Allergy Immunol. 2006;31:163-80.

45. Bonini M, Di Mambro C, Calderon MA, Compalati E, Schünemann H, Durham S, et al. Beta-2 agonists for exercise-induced asthma. Cochrane Database Syst Rev. 2013;10:CD003564.

46. Bonini M. Beta-2 agonists for exercise-induced bronchoconstriction in children. Paediatr Respir Rev. 2014;15(1):42-4

47. Bonini M, Permaul P, Kulkarni T, Kazani S, Segal A, Sorkness CA, et al. Loss of salmeterol bronchoprotection against exercise in relation to ADRB2 Arg16Gly polymorphism and exhaled nitric oxide. Am J Respir Crit Care Med. 2013;188(12):1407-12.

48. Salpeter SR, Ormiston TM, Salpeter EE. Meta-analysis: respiratory tolerance to regular beta2-agonist use in patients with asthma. Ann Intern Med. 2004;140:802-13.

49. Hancox RJ, Subbarao P, Kamada D, Watson RM, Hargreave FE, Inman MD Beta2-agonist tolerance and exercise-induced bronchospasm. Am J Respir Crit Care Med. 2002;165(8):1068-70. 
50. US Food and Drug Administration. www.fda.gov Accessed on November 20, 2014

51. Boaventura LC, Araujo AC, Martinez JB, Vianna EO. Effects of ipratropium on exercise-induced bronchospasm. Int J Sports Med. 2010;31(7):516-20. doi:10.1055/s-0030-1249624. Epub 2010 May 12.

52. Couto M, Silva D, Santos P, et al. Exploratory study comparing dysautonomia between asthmatic and non-asthmatic elite swimmers. Rev Port Pneumol. 2014. [Epub ahead of print]

53. Moreira A, Bonini M, Garcia-Larsen V, Bonini S, Del Giacco SR, Agache I, et al. Weight loss interventions in asthma: EAACl evidence-based clinical practice guideline (part I). Allergy. 2013;68(4):425-39.

54. ElHalawani SM, Ly NT, Mahon RT, Amundson DE. Exhaled nitric oxide as a predictor of exercise-induced bronchoconstriction. Chest. 2003:124 (2):639-43.

55. Zietkowski Z, Skiepko R, Tomasiak-Lozowska MM. RANTES in exhaled breath condensate of allergic asthma patients with exercise-induced bronchoconstriction. Respiration. 2010;80(6):463-71.

56. Hilberg T. Etiology of exercise-induced asthma: physical stress-induced transcription. Curr Allergy Asthma Rep. 2007;7(1):27-32

57. Bonini M, Marcomini L, Gramiccioni C. Microarray evaluation of specific lgE to allergen components in elite athletes. Allergy. 2012;67(12):1557-64.

58. Price OJ, Ansley L, Menzies-Gow A, Cullinan P, Hull JH. Airway dysfunction in elite athletes-an occupational lung disease? Allergy. 2013;68(11):1343-52.

\section{Submit your next manuscript to BioMed Central and take full advantage of:}

- Convenient online submission

- Thorough peer review

- No space constraints or color figure charges

- Immediate publication on acceptance

- Inclusion in PubMed, CAS, Scopus and Google Scholar

- Research which is freely available for redistribution 